\title{
Fungal laccase discovered but yet undiscovered
}

\author{
Komal Agrawal ${ }^{1}$, Venkatesh Chaturvedi ${ }^{2}$ and Pradeep Verma ${ }^{1 *}$
}

\begin{abstract}
Laccases belongs to multinuclear copper-containing oxidase and can act on a variety of aromatic and non-aromatic compounds. Due to their broad substrate specificity, they are considered as a promising candidate in various industrial and biotechnological sectors. They are regarded as a "Green Tool"/"Green Catalyst" in biotechnology. The present review focuses on structure, reaction mechanism, categories, applications, economic feasibility, limitations, and future prospects of fungal laccases. Thus, this review would help in understanding laccases along with the areas, which has not been focused and requires attention. Since past, immense work has been carried out on laccases: yet, new discoveries and application are ever increasing which includes bio-fuel, bio-sensor, fiber board synthesis, bioremediation, clinical, textile industry, food, cosmetics, and many more. Hence, it can be stated that fungal laccase is an enzyme which is "discovered but yet undiscovered".
\end{abstract}

Keywords: Laccase, Green tool, Biocatalyst, Application

\section{Introduction}

Laccases are $p$-diphenol:dioxygen oxidoreductase belonging to the family of multi-copper proteins. It was first isolated from the sap of Japanese lacquer tree Rhus vernicifera (Yoshida 1883) and are widely distributed in nature being found in plants, fungi, insects (Hattori et al. 2005), and bacteria. First bacterial laccase was discovered in Azospirillum lipoferum (Givaudan et al. 1993). Since bacterial laccases have low redox potential (Surwase et al. 2016), fungal laccases are more preferred owing to their high redox potential (Songulashvili et al. 2016) (Additional file 1: Table S1).

Laccases have the ability to oxidize a wide range of aromatic and non-aromatic compounds which includes substituted phenols, some inorganic ions, and variety of non-phenolic compounds (Matera et al. 2008; Songulashvili et al. 2016; Nguyen et al. 2016; Surwase et al. 2016). Due to its low substrate specificity, it can act on a broad range of substrates and has attracted considerable attention in different environmental, industrial,

\footnotetext{
*Correspondence: vermaprad@yahoo.com

1 Department of Microbiology, Central University of Rajasthan, N.H. 8

Bandarsindri, Kishangarh, Ajmer, Rajasthan 305817, India

Full list of author information is available at the end of the article
}

and biotechnological sectors (Afreen et al. 2016). Laccases have been regarded as a "Green Tool", because they require molecular oxygen $\left(\mathrm{O}_{2}\right)$ as the only co-substrate for bio-catalysis and not hydrogen peroxide $\left(\mathrm{H}_{2} \mathrm{O}_{2}\right)$ (Surwase et al. 2016). Laccases have the capability to reduce dioxygen to water by one-electron oxidation of substrate which are mainly substituted phenolic compounds.

Laccases have high catalytic efficiency and are used for technical applications in various industrial and biotechnological domains (Xenakis et al. 2016) which includes improving properties of fibers, bio-synthesis, energy exploitation, environmental protection, bio-detection, degradation of synthetic dyes, printing and dyeing industry, bio-pulping in paper industry, conversion of aromatic compounds (Zheng et al. 2016), and removal of phenols which causes cancer and teratogenicity when present in waste water (Pang et al. 2016). In addition, it is also used in fast moving consumer goods (FMCG) as tooth-paste, mouthwash, detergent, soap, and diapers in cosmetics as deodorants; in beverage and food industry for wine and juice stabilization (Piacquadio et al. 1998; Alper and Acar 2004; Surwase et al. 2016); in dough or baked products to increase strength of gluten structures; in pharmaceutical industries as anesthetics, anti-inflammatory drugs, antibiotics, and sedatives (Nicotra et al. 2004; Surwase et al. 
2016); and in nanobiotechnology as nanoparticle-based bio-sensors. However, laccases are not able to exhibit full efficiency under harsh conditions (Pang et al. 2016). Therefore, novel strains which can tolerate harsh conditions and give maximum enzyme production with minimum energy consumption are in huge demand.

The present review is an attempt to provide cumulative information on various aspects of fungal laccases, which includes information pertaining to the structure, reaction mechanism, categories, and industrial and biotechnological application of laccase.

\section{Structure and reaction mechanism of laccase}

Laccases are known to exist in a variety of forms; they can be monomeric, homotetrameric, heterodimeric, and multimeric. Their molecular weight ranges from 50 to $130 \mathrm{kDa}$ depending upon the organism (Jaiswal et al. 2015). The plant laccases approximately contains $45 \%$ carbohydrate content, whereas for fungal laccases, it is $10-30 \%$ of molecular weight (Baldrian 2006). It is assumed that the carbohydrate portion of laccase ensures the conformational stability of the protein part and protects the enzyme from proteolysis and inactivation by radicals (Morozova et al. 2007). The primary structure of laccases consists of Greek key $\beta$ barrel topology which constitutes of approximately 500 amino acid residues organized in three consecutive domains. These amino acids are distributed in three domains: first domain with 150 initial amino acids, second domain with 150 and 300 amino acid, and third domain with 300-500 amino acids. The stabilization of laccase structure is due to the presence of disulphide bonds between domains I and II and between domains I and III (Bertrand et al. 2002; Ferraroni et al. 2007; Matera et al. 2008; Plácido and Capareda 2015). However, in Melanocarpus albomyces, three disulfide bridges are present of which one is inside domain I, another between domain I and domain III, and the last one between domain II and III (Hakulinen et al. 2002).

Laccases are known to exist in four different $\mathrm{Cu}$ catalytic forms per protein unit. These four $\mathrm{Cu}$ ions are divided into three types of structures:

\section{Type 1: paramagnetic 'blue' copper}

Type 1 copper confers blue color to multi-copper proteins, which is due to the intense electronic absorption caused by the covalent copper-cysteine bond. Due to its high redox potential of ca. $+790 \mathrm{mV}$, substrate oxidation takes place at the Type 1 copper site and has an absorbance at $610 \mathrm{~nm}$ (Matera et al. 2008). Type 1 copper has a trigonal coordination, with two histine and a cysteine as conserved equatorial ligands and one position usually variable, and in case of fungal laccases, the axial ligand is leucine or phenylalanine. It has even been argued that the axial position ligand influences the oxidation potential of the enzyme, which possibly provides the mechanism for regulating its activity (Fig. 1) (Claus 2004; Kumar et al. 2003; Enguita 2011; Garavaglia et al. 2004).

\section{Type 2: paramagnetic "normal/non-blue" copper}

Type 2 or normal $\mathrm{Cu}$ site (Niku-Paavola et al. 2004) is characterized by the lack of strong absorption features in the visible region and reveals usual electron paramagnetic resonance (EPR) spectra. Type 2 copper is coordinated by two histidines residues and is strategically positioned close to Type 3 copper.

\section{Type 3: diamagnetic spin-coupled copper-copper pair}

It is a binuclear center regulated by six histidines and spectroscopically characterized by an electron adsorption at $330 \mathrm{~nm}$ (oxidized form) and absence of an EPR signal due to the strong anti-ferromagnetical coupling between the two Type 3 copper atoms which is related to the presence of a hydroxyl bridge (Matera et al. 2008). The Type 2 copper and Type 3 copper form a tri-nuclear cluster where molecular oxygen is reduced and release of water takes place. An example of one-electron oxidation of phenolic hydroxyl groups, while reducing oxygen and forming phenoxy radicals along with water are represented below (Felby et al. 2004):

$$
4 \mathrm{Phe}-\mathrm{OH}+\mathrm{O}_{2} \stackrel{\text { laccase }}{\longrightarrow} 4 \mathrm{Phe}-\mathrm{O} \cdot+2 \mathrm{H}_{2} \mathrm{O}
$$

The Type 3 copper centers also have common feature of another protein super-family which includes the tyrosinases and haemocyanins (Decker and Terwilliger 2000).

\section{Reaction mechanism of laccase: direct and in-direct oxidation}

The basic reactions catalyzed by laccase can be of two types: direct oxidation and in-direct oxidation. The direct oxidation involves the oxidation of substrate to the corresponding radical as a result of direct interaction that occurs with copper cluster (Matera et al. 2008) (Fig. 2a). However, in certain reactions, direct oxidation is not feasible as laccase can only oxidize those compounds whose ionization potential does not exceed redox potential of T1 copper ion (Morozova et al. 2007). Nevertheless, the limitation can be overcome by the use of mediator which is a two-step process: first enzyme catalyzes the oxidation of the mediator and then the oxidized mediator oxidizes the substrate (Fig. 2b). However, for the reaction to occur without any obstruction, certain features should be exhibited by the mediator: (a) the reaction should occur without any hindrance, (b) it must be good substrate for laccase both in its oxidized and reduced forms, (c) it 


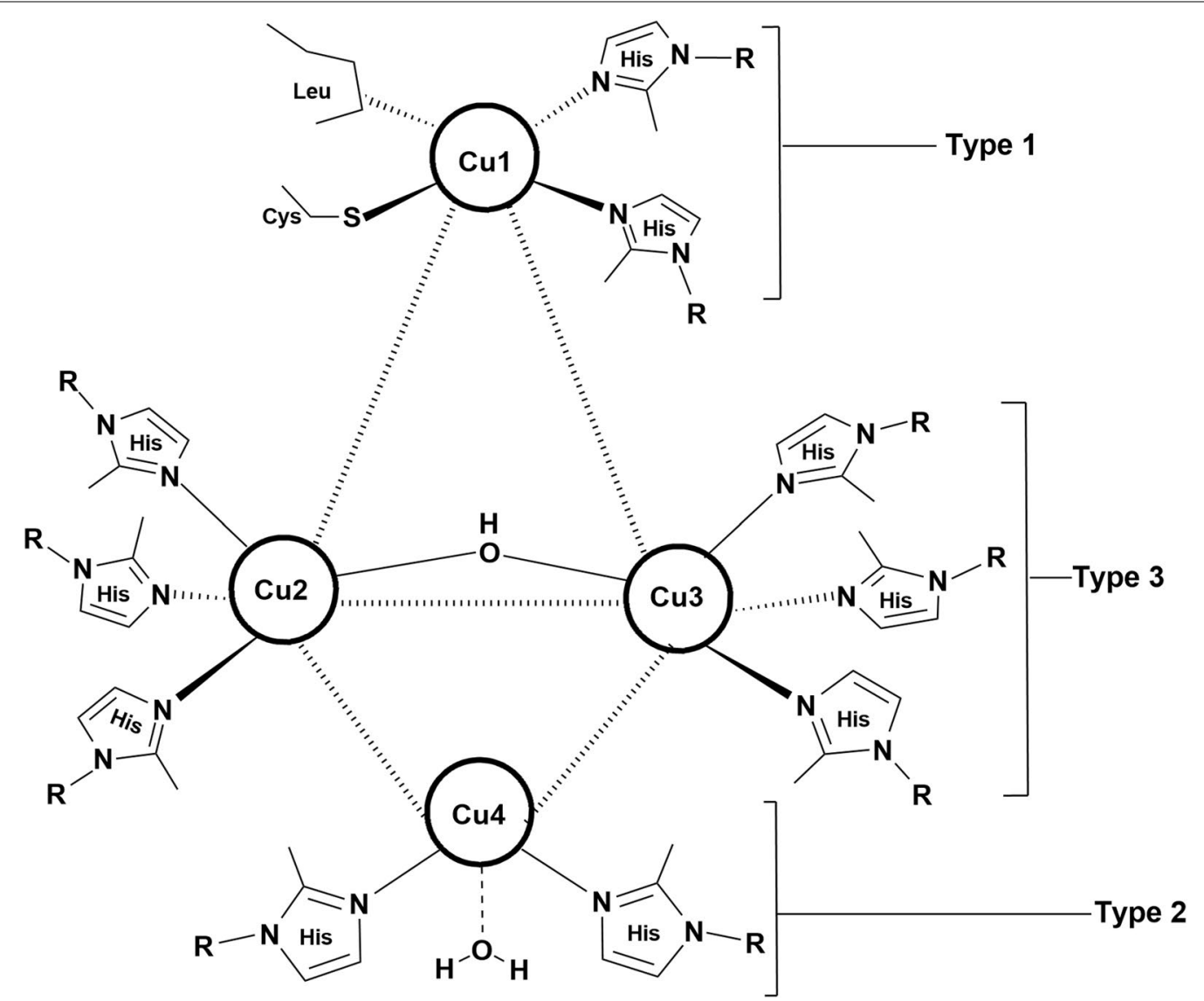

Fig. 1 Copper centers of laccase: Type 1, Type 2, and Type 3 (Adapted and modified axial ligand as leucine as per fungal laccases by Garavaglia et al. (2004))

should be stable; it must not inhibit enzymatic reaction, and $(\mathrm{d})$ conversion must be cyclic in nature (Johannes and Majcherczyk 2000).

Besides mediators, the use of inducer to enhance laccase production has been widely practiced in fungi especially in the white rots where metals, aromatic compounds, and phenolic compounds (Terrón et al. 2004) have been used as inducers. Conversely, there are certain substances which can inhibit the production of laccase and are known as the inhibitors such as sodium azide and dithiothreitol DTT (Additional file 1: Table S2).

\section{Categories of laccase}

\section{White laccase}

The white laccase exhibits neutral $\mathrm{pH}$ and has anomalous metal content which is responsible for its unique characteristic (Palmieri et al. 1997). It exhibits absorption peak at $400 \mathrm{~nm}$ but absence of peak at $605 \mathrm{~nm}$ [T1 copper site] and $330 \mathrm{~nm}$ [T3 binuclear copper]. White laccase does not exhibit EPR spectra as well as T1 and T2 signals (Zhao et al. 2012). The reason for the colorlessness could be due to the change in the valence state of the $\mathrm{Cu}^{2+}$, and no detection of EPR signal can be due to $\mathrm{Fe}^{2+}$ which has low spin rate electron configuration. It was not deduced as to which copper was replaced with iron, but it was conferred that the lack of absorbance at $605 \mathrm{~nm}$ can be due to the incomplete oxidation state of copper which has fully occupied electron configuration of $\mathrm{d}^{10}$ and no d-d transition (Zhao et al. 2012) and may be responsible for extra high activity of protein. White laccase has been considered under laccase family, because the primary structure of the white laccase is identical to those of known laccase and it uses oxygen $\left(\mathrm{O}_{2}\right)$ as an oxidative substrate. There is the absence of the formation of hydrogen peroxide $\left(\mathrm{H}_{2} \mathrm{O}_{2}\right)$ as the product of catalyzed reaction and substrate specificity exhibited is also the same as that of known laccase (Palmieri et al. 1997), e.g., Lepista nuda-molecular mass of $56 \mathrm{kDa}$ (Zhu et al. 2016).

Few strains reported for white laccase production include Pleurotus ostreatus (Palmieri et al. 1997) and Myrothecium verrucaria NF-05 (Zhao et al. 2012). These strains besides single copper atom consist of various 


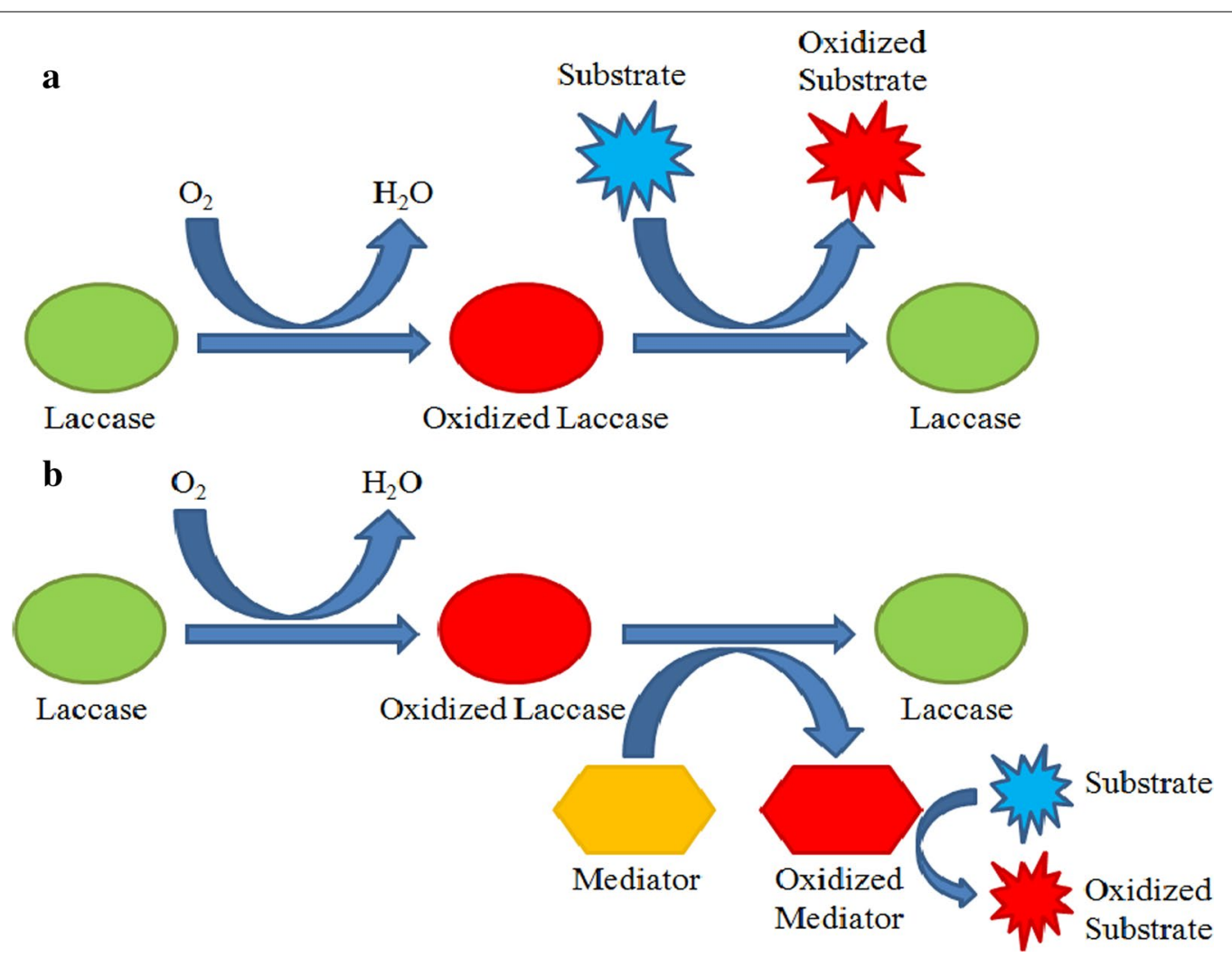

Fig. 2 Schematic representation of reaction catalyzed by laccase; a direct oxidation: the substrate is oxidized to the corresponding radical as a result of direct interaction and $\mathbf{b}$ in-direct oxidation: the substrate is oxidized in the presence of a mediator

metal subunits; for Pleurotus, it consist of one copper, two zinc, and one iron atoms (Palmieri et al. 1997); and Myrothecium verrucaria NF-05 consist of three copper and one iron atoms (Zhao et al. 2012).

\section{Yellow laccase}

Yellow laccase is artificially reduced blue laccase as it does not have absorption at $600 \mathrm{~nm}$ and EPR spectrum (Leontievsky et al. 1997; Pozdnyakova et al. 2006). Alteration of blue-to-yellow laccase can occur by the reduction of type I copper site by aromatic product of lignin degradation or binding of specific amino acid of enzyme polypeptide to a molecule of modified product produced by lignin degradation; it can also be due to heterogeneity induced by glycosylation (Mot et al. 2012). The modified molecule bound to the apoenzyme performs the function of electron-transfer mediator analogous to the role of 2,2-azinobis(3-ethylbenzthiazoline-6-sulfonic acid) diammonium salt (ABTS) or other compounds in the reaction of blue laccase (Leontievsky et al. 1997), hence having high redox potential which allows them to oxidize non-phenolic compounds without any mediators (Mot et al. 2012) and having greater industrial potential (Daroch et al. 2014). The change in protein conformation may explain the sensitivity of yellow laccase to $\mathrm{CO}$ and other inhibitors, e.g., P. tigrinus (Leontievsky et al. 1997). At present, information about the purification and characterization of yellow laccase is extremely limited and their catalytic properties are still seldom investigated. Much work has not been done on the yellow laccase, but a few strains which are reported for the production of yellow laccase are as follows P. tigrinus (Leontievsky et al. 1997), S. aeruginosa, G. fornicatum (Daroch et al. 2014), P. ostreatus (Pozdnyakova et al. 2004), Panus tigrinus 8/18, Phlebia radiate, Phlebia tremellosa, Pleurotus ostreatus D1 (YLPO) (Pozdnyakova et al. 2004), Sclerotinia sclerotiorum (Mot et al. 2012), and Panus tigrinus (Leontievsky et al. 1997).

\section{Industrially important laccase}

The enzyme required for the industrial application should have the ability to tolerate wide range of $\mathrm{pH}$ and temperature and it needs to be operational under industrial conditions. Thus, alkaline-tolerant and thermo-stable laccase are desired by the industries, but due to limited information, its application has not been feasible at a commercial scale. However, these limitations can be overcome by the use of various immobilization techniques which can help 
to enhance the stability of laccase, thus enabling its use at industrial scale (Additional file 1: Table S3).

\section{Alkaline-tolerant and thermo-stable laccase}

Alkaline-tolerant laccases have their utility in a number of industrial areas, but their application is not possible at commercial scale as very few laccase have been identified till date, e.g., in hair coloring industries, alkaline-tolerant laccase is more preferred. In the work done by Saito et al. (2012), laccase was used for the development of hair coloring products which was functional at $\mathrm{pH}$ 9. Similarly, Singh et al. (2007) isolated fungal strain which could tolerate $\mathrm{pH}$ range of 4-10 and was used for the degradation of indigo carmine dye. However, more research is required for the efficient isolation and identification of enzyme which are able to tolerate various $\mathrm{pH}$ ranges and have its application in the industrial sector.

Laccases exhibit great industrial potential, but due to limitations such as less stability, less tolerance to high temperatures, expensive stimulators, and purification processes, its application is restricted. Activated thermostable enzyme was reported by Coll et al. (1993), and from various studies carried out, it was found that packing of protein increases the content of helical fold, density of $\mathrm{H}$ bonds, salt bridges, distribution of charged residues, proportions of amino acids, and glycosylation. The above-mentioned factors are responsible for enhancing thermo-stability of the enzyme (Kumar and Nussinov 2001). However, intense study is required which could help in the identification of thermo-stable laccase for its utilization in the industrial sector (Additional file 1: Table S4).

\section{Applications of laccase in various industrial and biotechnological fields}

Laccases due to their catalysis have applications in wide array of industrial and biotechnological sectors. Some important areas are as follows (Fig. 3).

\section{Advance bio-fuel: production of biogas and bio-ethanol}

The utilization of second-generation bio-fuels such as biogas and bio-ethanol is regarded as 'greener' approach as they are produced from sustainable feedstocks. Laccases are intensively investigated for the pretreatment of lignocellulosic materials for the production of bio-ethanol or biogas as it increases the fermentability of lignocellulosic materials through lignin degradation (Tabka et al. 2006). Various physical and chemical pretreatment processes are used to minimize the effect of lignin, but enzymatic approaches such as lignin oxidization or delignification either singly or in combination with other pretreatment methods are considered as they are ecofriendly and economically feasible process (Kudanga and Le Roes-Hill 2014). Delignification by laccase is carried out with mediators due to the low redox potential of laccase, complexity, and size of lignocelluloses materials. It can easily oxidize; oxidizable phenolic units at the surface of the substrate which constitutes less than $10 \%$ of the polymer. Laccase mediator system (LMS) generates

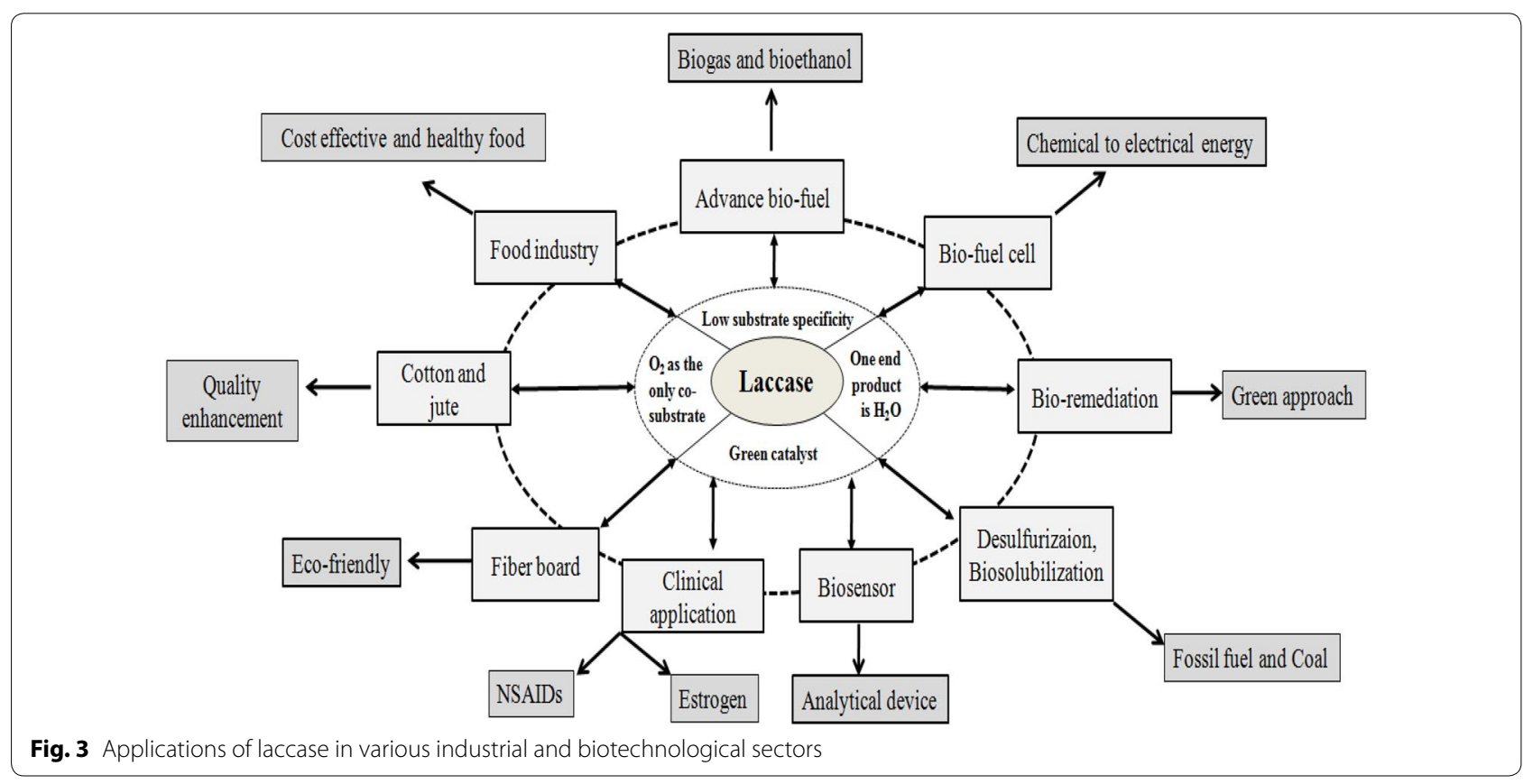


radicals which can cleave covalent bonds in lignin as they can oxidize both phenolic and non-phenolic lignin components (Kudanga and Le Roes-Hill 2014).

Recently, a system that uses immobilized laccase for detoxifying lignocelluloses hydrolysates was developed (Ludwig et al. 2013). Laccase treatment can be accomplished using free purified laccase or whole cells which produce the enzyme. However, when whole cells are used, it becomes difficult to find a direct correlation among enzyme production, lignin degradation, and sugar yield (Salvachúa et al. 2011; Yamagishi et al. 2011). The majority of delignification processes catalyzed by laccase and LMS are either for research purposes or for the purposes of bio-pulping ( $\mathrm{Du}$ 2013), and can be used for biogas or bio-ethanol production (Kudanga and Le Roes-Hill 2014).

\section{Bio-fuel cell-an eco-friendly tool to generate low-voltage electricity}

Bio-fuel cell can be described as cell which converts chemical energy to electrical energy, with the help of microorganisms (Chaturvedi and Verma 2016). It is considered as a clean technique for generating electricity without emission of green house gas (Zebda et al. 2012). They have the capability to supply electricity to devices which requires low energy input. The advantages associated with bio-fuel cells are that the enzyme coat are cheap and economically feasible, replacement is easy and convenient (Nazaruk et al. 2008), and the activity can be performed at room temperature, neutral pH (Fig. 4) (Kulys and Vidziunaite 2003). Laccase has been used in the synthesis of bio-fuel cells due to its ability to oxidize phenols, and reduction of oxygen to water by four electron transfer at high redox potential (Zheng et al. 2008), which is an important application of laccase in the cathode compartment of bio-fuel cells (Quan et al. 2004). However, due to the complex redox centers, orientation of laccase at the electrodes and electrical insulation of bio-catalytic site formed by surrounding protein shells (Zebda et al. 2012) inhibits direct transfer of electron. Thus, to solve the problem of shuttling, electrons are mediated by the help of redox mediators like ABTS and osmium-based polymers (Zheng et al. 2008) which results in in-direct oxidation. The performance of glucose bio-fuel cells (GBFC) is largely governed by the materials of the electrodes used and the mechanism of their assembly on the electrode surface (Zebda et al. 2012).

\section{Bioremediation of the environment and detoxification of effluents}

Today, world is witnessing very high level of pollution by xenobiotic compounds. Some of the chemicals are potent carcinogen and mutagen. The traditional physical

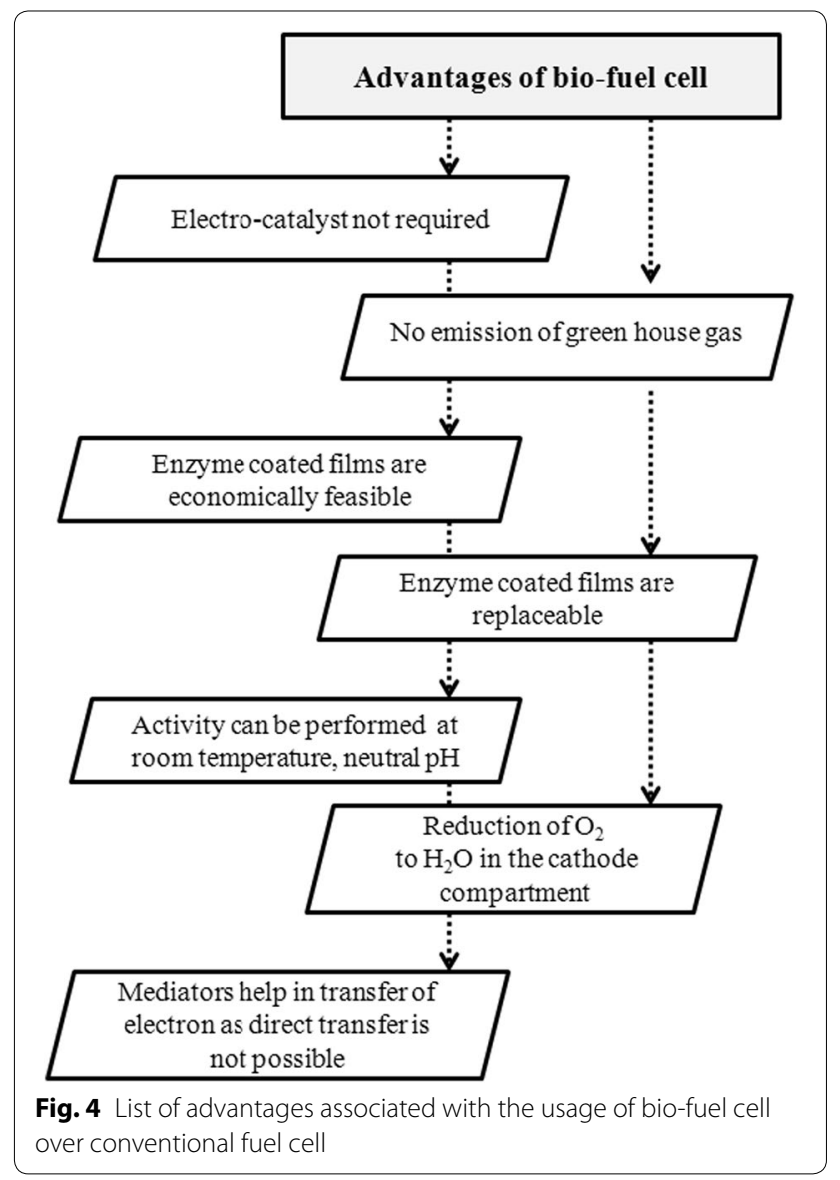

and chemical treatment processes are widely used for the treatment of these pollutants; however, the processes are costly and require sophisticated instruments. Thus, the use of enzymes for removal of aromatic pollutants is considered as an eco-friendly, cost-effective, and efficient step in bioremediation. Laccases are currently employed in bioremediation of chlorophenols, polycyclic aromatic hydrocarbons, lignin-related structures, organophosphorus compounds, phenols, and azo dyes (Saratale et al. 2011; Khan et al. 2013; Viswanath et al. 2014). The biodegradation of a mixture of pentachlorophenol (PCP), 2-chlorophenol (2-CP), 2,4-dichlorophenol (2,4-DCP), and 2,4,6-trichlorophenol (2,4,6-TCP) using fungal laccases produced by Trametes pubescens was evaluated by Gaitan et al. (2011). Laccases are also able to metabolize dichlorodiphenyltrichloroethane (DDT) in soil (Zhao et al. 2010) and biodegrade 2,4-dichlorophenol (Bhattacharya et al. 2009).

Fungal laccases are used in the decolorization and detoxifications of effluents discharged from industries (Chandra and Chowdhary 2015) like food, textile, pulp/ paper, and plastic (Viswanath et al. 2014) which pollute water due to the release of colored effluents and by the 
formation of carcinogenic intermediates such as aromatic amines from azo dyes (Mahmoodi et al. 2009). Dyes are usually resistant to fading on exposure to light due to their complex chemical structure and synthetic origin (Lin et al. 2010). Since the conventional dye treatment systems are very expensive and consume high amounts of chemicals and energy biological treatment seems to be an effective alternative. The use of laccase in dye degradation has been studied and they act on chromophore compounds such as azo, anthraquinone, heterocyclic, indigoid dyes, polymeric dyes, remazol brilliant blue $\mathrm{R}$, triarylmethane, and triphenylmethane (Abadulla et al. 2000). The enzymes due to their specificity attack only the dye molecules as a result of which valuable dyeing additives and fibers are kept intact. Thus, being an effective method to bioremediate the environment of the toxic dye effluents.

Laccase has also been used in paper making to increase its strength related properties with the help of ferulic acid applied in sisal pulp (Aracri et al. 2011). It has also been grafted with natural phenols in unbleached fibers along with the analysis of antibacterial activity (Elegir et al. 2008). The industrial preparation of paper requires the use of chemicals which actually causes environmental pollution. However, LMS can be used as an eco-friendly tool where the use of chlorine-based treatment process can be minimized. It has already found practical applications in Lignozym ${ }^{\circledR}$-process (Call and Mücke 1997). However, bio-bleaching studies were focused on wood pulps and Camarero et al. (2004) explored the potential of LMS to remove lignin-derived products responsible for color from high-quality flax pulp. They showed the feasibility of LMS to substitute chlorine-containing reagents in manufacturing of these high-priced paper pulps.

\section{Desulfurization and bio-solubilization}

Laccase can be used for the desulfurization of harmful sulfur containing compounds which are generally emitted during the post-combustion or pre-combustion of fossil fuel. Similarly, bio-solubilization can help in the generation of low grade ores and liquid fuels from coal (Arora and Sharma 2010).

\section{Bio-sensor-a new approach having multiple usages}

Bio-sensors can be developed by the aid of single- or multi-enzyme system (Kulys and Vidziunaite 2003). It can be defined as an "analytical device that combines biological material (e.g., enzymes, cells, microorganisms, tissues, etc.) with an appropriate transducer (e.g., optic, electrochemical, calorimetric, piezoelectric, etc.) capable to give selective/quantitative analytical information" (Leite et al. 2003). The work on bio-sensors was initially initiated by Guilbault and co-workers on amperometric bio-sensors which emphasized mainly on clinical applications of bio-sensors. It has been used in clinical field for the determination of dopamine (Xiang et al. 2007). However, at present, research has diverted towards the determination of phenols and its control (Kulys and Vidziunaite 2003).

The biological material in the bio-sensor generates signal which is later converted to response and can be of various types like current, temperature, etc. The desired feature which needs to be present in bio-sensor are application-dependent sensitivity, selectivity, reversibility, speed, and a long lifetime with the minimal power consumption and sample volume (Leite et al. 2003).

Mousty et al. (2007) developed the concept of biosensor devices for the reagent-less detection of laccase inhibitors and modulators. As an end result, several phenol bio-sensors based on laccase have been fabricated as they have high selectivity, convenience, reliability, and high sensitivity (Mei et al. 2015). Various researchers have worked on the field for creating bio-sensors with the help of laccase for the detection of phenols (Cabaj et al. 2011; Nazari et al. 2015), pesticides, and laccase inhibitors (Mousty et al. 2007). The combination of twoenzyme system has also been developed to determine the synergistic effect in the detection of the desired product or pollutant (Leite et al. 2003; Medina-Plaza et al. 2014).

\section{Clinical application of laccase}

Initially, laccases were used in bio-sensors for clinical applications; however, other applications of laccase in clinical sector were exploited which includes its usage in the removal of clinically generated pollutants from the environment for, e.g., the non-steroidal anti-inflammatory drugs (NSAIDs) usually found in the aquatic environments which damages liver and kidney of animals consuming water from the sites contaminated with drugs. This has lead to rapid decline in vulture population in India and Pakistan. Thus, removal of this pollutant NSAIDS, e.g., naproxen and diclofenac, which has accumulated in the environment can be achieved by the use of laccase (Lloret et al. 2013). Other clinically generated pollutant include estrogen's whose main component estriol produced in urine, placenta during pregnancy, and primary estrogens are produced by adipose tissues of males and post-meno-pausal women which causes pollution of aquatic body. Laccase can be used for the treatment of the water body polluted with estrogens or its components (Ueda et al. 2012). As the removal cost at the water treatment plant is high and requires high energy, laccase can provide cheap treatment and operational activity at room temperature. 
The other aspect includes fungal laccase from A. cylindracea, it exhibits anti-proliferative activity against cancer cells and inhibitory activity toward the HIV-1 reverse transcriptase (Hu et al. 2011). The strain Inonotus abaumii also exhibits anti-proliferative activity against the cancer cells (Sun et al. 2014).

\section{Fiberboard synthesis from laccase: an eco-friendly approach}

Fiberboard consists of wood-based materials joint together by synthetic adhesive which in most of the cases is formaldehyde. The main disadvantage of using formaldehyde based adhesive is the release of formaldehyde from fiber board and its exposure to humans as a potent carcinogen. Thus, to substitute formaldehyde, laccase has been used in the treatment of fibers to make fiberboard which are much better in contrast to boards made from untreated fibers (Fig. 5). It gives better fiber-to-fiber interaction and better transfer of fiber-to-fiber stress. One more advantage of enzyme treated fiber includes increase in the hydrophobicity which gives an indication that lignin of the fiber has precipitated to the surface making it water repellent also resulting in the change of the chemical composition of the fiber (Felby et al. 2004). Other approach in production of fiberboard is lignin polymerization. In this method, laccase is used for the oxidation of lignin which produces large number of free radicals which are highly reactive and can catalyze a number of reactions such as polymerization, copolymerization, and grafting which are important reactions during fiberboard synthesis (Saastamoinen et al. 2012; Felby et al. 2004).

\section{Cotton and jute}

Laccase has its utility in cotton and jute industry, as well. The laccase TEMPO oxidation was used for grafting octadecylamine onto cotton fibers to obtain hydrophobic nature of the fiber that increased after enzymatic treatment of laccase was applied (Yu et al. 2016).

Jute increases binding capacity of composite but has disadvantage due to its hydrophilic nature, which can be overcome by the treatment of jute by laccase. The treatment helped in increasing the hydrophobicity and improved composite synthesis which would eventually enhance the properties of jute fibers. In jute industry grafting was done by dodecyl gallate (DG) and laccase to increase the hydrophobicity of the fiber to enhance the composite reinforcement (Dong et al. 2014).

\section{Food industry: a new approach}

Laccase is used in food industry for the production of economically feasible and healthy foods (Brijwani et al. 2010). For instance, browning of fruit juices is a major drawback in beverage industry and can be overcome by the use of laccase (Ribeiro et al. 2010). In bread making, laccase is added as an additive to the bread dough

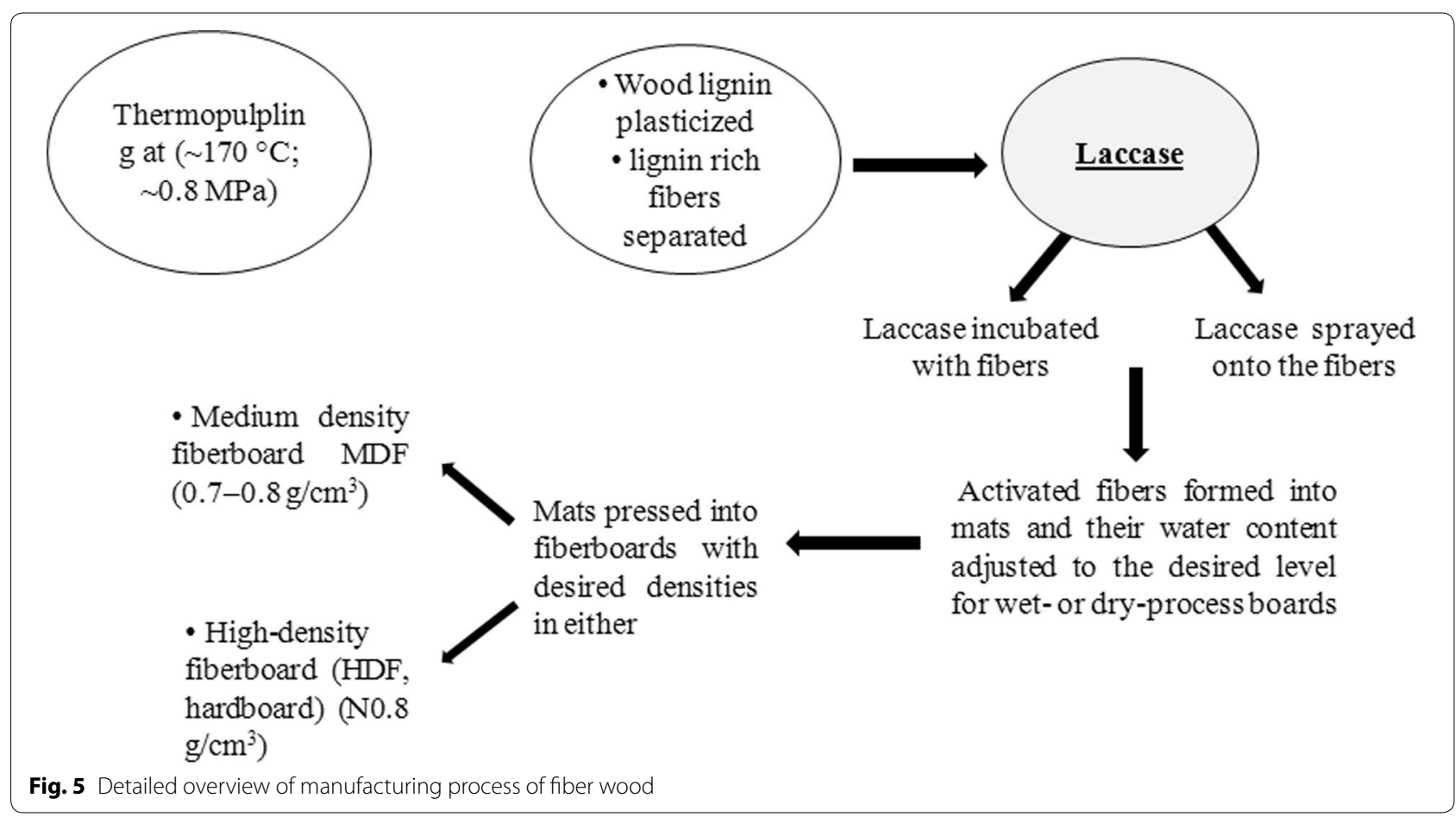


which improved flavor, texture, volume, and freshness of the bread. Laccase also increased the crumb structure, volume, and softness of bread (Selinheimo et al. 2006).

Fruit juices contain various phenolics which impart color and taste to the juice. Oxidation of these compounds is employed to increase the stability of fruit juices. Naturally occurring phenolics and their oxidation products are present in many fruit juices which are responsible for its color and taste. The natural co-oxidation reactions result in unwanted changes in aroma and color, which increases due to a higher concentration of polyphenols and polymerization of phenols and polyphenols in the fruit juices. The treatment of laccase decreases the phenolic content of juices and enhances the color stability of apple juice (Ribeiro et al. 2010).

\section{Commercialization of laccase}

The study by Osma et al. (2011) focused on the expenditure associated with the production of laccase from white-rot fungus Trametes pubescens. It showed that the cost of production is low, but the cost associated with downstream processes such as purification of laccase is high. The purification process increases the overall cost of production, thereby hindering its commercialization. Thus, research should be focused in the development of better and cost-effective methods for large-scale production and commercialization. The commercialization of laccase scale would enable the development of "greener" approach for "clean" environment as it would contribute in bioremediation of the environment, chemical-free treatment in industries, development of chemical-free product, e.g., hair coloring, and detection of pollutants as it can be used as bio-sensors.

\section{Limitations and future prospect}

Since the discovery of laccase application has increased in various industrial sectors. However, there are various limitations associated with laccase and its utilization. Thus, research now has to be diverted towards the "not so focused" aspects of laccase, so that the applications of the enzyme could be further broadened (Fig. 6).

Discovery of novel enzyme with interesting activities, e.g., intracellular, yellow and white laccase and alkaline or $\mathrm{pH}$-tolerant laccase which can remain active in industrial operating condition with enhanced lifetime of laccase activity needs to be identified. Improvement of enzyme activity and stability through immobilization and protein engineering will help to obtain more robust and active enzyme which will help boost its exploitation, reutilization, and production, thereby enabling commercialization. Study should also focus on thermodynamics and physiological properties affecting catalytic performance of laccase.

Industrialization if possible at large scale can help solve many environmental-related issues and can efficiently help in bioremediation of the environment in healthier, greener, and cleaner way.

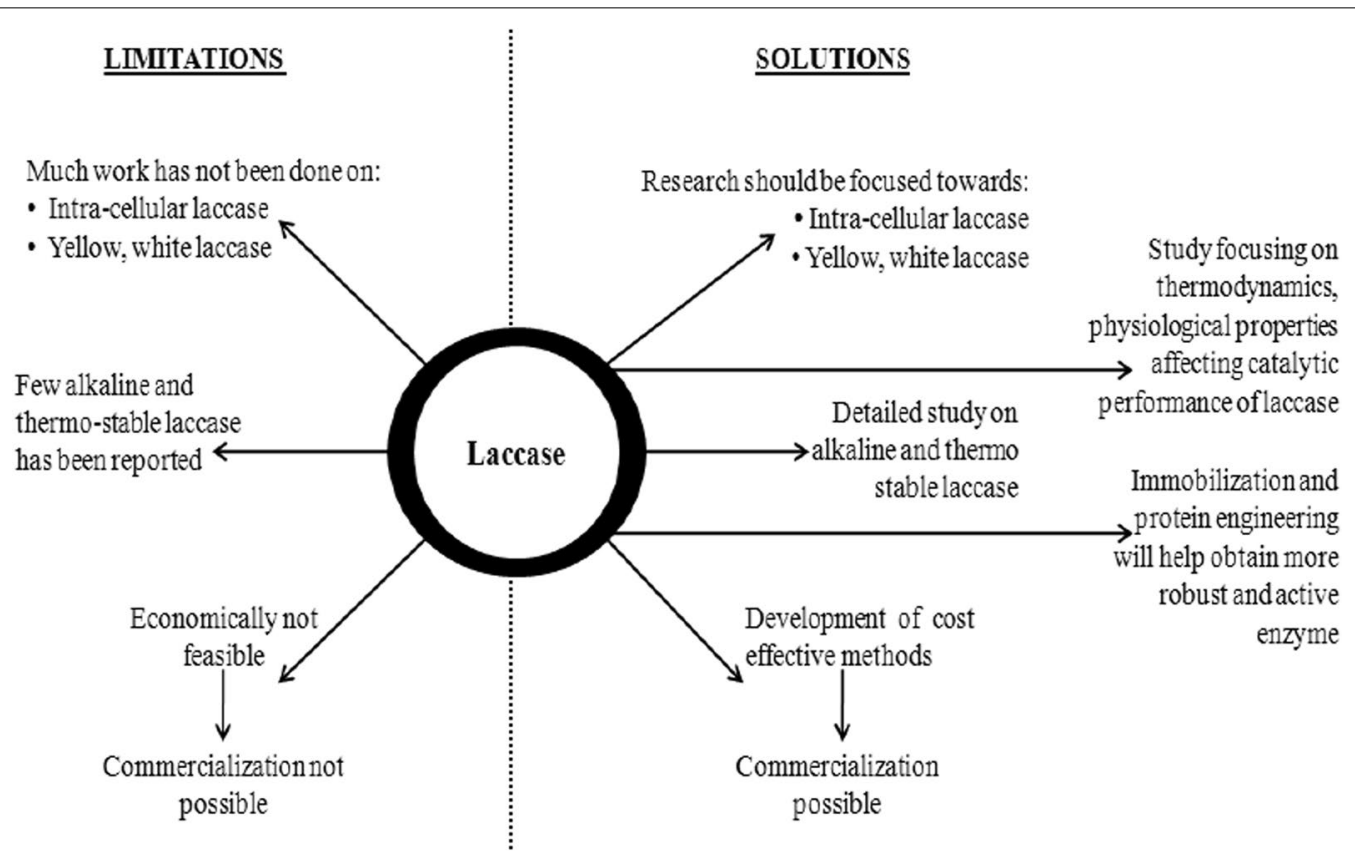

Fig. 6 Limitations associated with laccase and its possible solutions 
Thus, research now has to be diverted towards the "not so focused" aspects of laccase, so that the applications of the enzyme could be further broadened.

\section{Conclusion}

This review clearly demonstrates that laccase is one of the most important enzymes being used in different areas of biotechnology such as food technology, medicine, bioremediation of xenobiotics and pollutants, fiberboard synthesis, etc. This suggests that laccases are essential in the field of biotechnology, which can address the problem of pollution and ecological imbalance caused by largescale use of chemicals in various industrial processes. It felts that still research is required in this field, so that new strains capable of producing industrially important laccase are isolated and applied on commercial scale. Thus, much work needs to be done on laccase and it can be correctly stated that fungal laccase is an enzyme which is "discovered but yet undiscovered".

\section{Additional file}

Additional file 1: Table S1. Various fungal strains reported for laccase production. Table S2. List of mediator, inducer and inhibitor of laccase production. Table S3. Materials used for the immobilization of laccase. Table S4. Fungal strain producing thermostable $\left(>50^{\circ} \mathrm{C}\right)$ laccases.

\section{Abbreviations}

FMCG: fast moving consumer goods; LMS: laccase mediator system; GBFC: glucose bio-fuel cells; NSAIDs: non-steroidal anti-inflammatory drugs; DTT: dithiothreitol; ABTS: 2,2-azinobis(3-ethylbenzthiazoline-6-sulfonic acid) diammonium salt; EPR: electron paramagnetic resonance.

\section{Authors' contributions}

KA performed the literature survey; KA and VC studied the papers and prepared the MS; PV planned and supervised the whole work. All authors read and approved the final manuscript.

\section{Author details}

${ }^{1}$ Department of Microbiology, Central University of Rajasthan, N.H. 8 Bandarsindri, Kishangarh, Ajmer, Rajasthan 305817, India. ${ }^{2}$ SMW College, MG Kashi Vidyapeeth, Varanasi 221005, U.P., India.

\section{Acknowledgements}

PV is thankful to DBT (Grant No. BT/304/NE/TBP/2012) and KA is thankful to Central University of Rajasthan, Ajmer, India for providing the financial support.

\section{Competing interests}

The authors declare that they have no competing interests.

\section{Availability of data and materials \\ Not applicable.}

\section{Consent for publication}

Not applicable.

\section{Ethics approval and consent to participate} Not applicable.

\section{Funding}

This work was supported by a DBT (Grant No. BT/304/NE/TBP/2012) and Central University of Rajasthan, Ajmer, India.

\section{Publisher's Note}

Springer Nature remains neutral with regard to jurisdictional claims in published maps and institutional affiliations.

Received: 9 November 2017 Accepted: 22 January 2018

Published online: 31 January 2018

\section{References}

Abadulla E, Tzanov T, Costa S, Robra KH, Cavaco-Paulo A, Gübitz GM (2000) Decolorization and detoxification of textile dyes with a laccase from Trametes hirsuta. Appl Environ Microbiol 66(8):3357-3362

Afreen S, Anwer R, Singh RK, Fatma T (2016) Extracellular laccase production and its optimization from Arthrospira maxima catalyzed decolorization of synthetic dyes. Saudi J Biol Sci. https://doi.org/10.1016/j.sjbs.2016.01.015

Alper N, Acar J (2004) Removal of phenolic compounds in pomegranate juices using ultrafiltration and laccase-ultrafiltration combinations. Food/Nahrung 48(3):184-187

Aracri E, Roncero MB, Vidal T (2011) Studying the effects of laccase-catalysed grafting of ferulic acid on sisal pulp fibers. Bioresour Technol 102(16):7555-7560

Arora DS, Sharma RK (2010) Ligninolytic fungal laccase and their biotechnological applications. Appl Biochem Biotechnol 160(6):1760-1788

Baldrian P (2006) Fungal laccase-occurrence and properties. FEMS Microbiol $\operatorname{Rev} 30(2): 215-242$

Bertrand T, Jolivalt C, Briozzo P, Caminade E, Joly N, Madzak C, Mougin C (2002) Crystal structure of a four-copper laccase complexed with an Arylamine: insights into substrate recognition and correlation with kinetics. Biochemistry 41(23):7325-7333

Bhattacharya SS, Karmakar S, Banerjee R (2009) Optimization of laccase mediated biodegradation of 2,4-dichlorophenol using genetic algorithm. Water Res 43(14):3503-3510

Brijwani K, Oberoi HS, Vadlani PV (2010) Production of a cellulolytic enzyme system in mixed-culture solid-state fermentation of soybean hulls supplemented with wheat bran. Process Biochem 45(1):120-128

Cabaj J, Sołoducho J, Chyla A, Jędrychowska A (2011) Hybrid phenol biosensor based on modified phenoloxidase electrode. Sens Actuators B Chem 157(1):225-231

Call HP, Mücke I (1997) History, overview and applications of mediated lignolytic systems, especially laccase-mediator systems (LignozymR process). J Biotechnol 53:163-202

Camarero S, Garcia O, Vidal T, Colom J, del Rıo JC, Gutiérrez A, Gras JM, Monje R, Martınez MJ, Martınez ÁT (2004) Efficient bleaching of non-wood high-quality paper pulp using laccase-mediator system. Enzyme Microb Technol 35:113-120

Chandra R, Chowdhary P (2015) Properties of bacterial laccase and their application in bioremediation of industrial wastes. Environ Sci Process Impacts 17:326-342

Chaturvedi V, Verma P (2016) Microbial fuel cell: a green approach for the utilization of waste for the generation of bioelectricity. Bioresour Bioprocess 3(1):38

Claus H (2004) Laccases: structure, reactions, distribution. Micron 35(1):93-96

Coll PM, Fernandez-Abalos J, Villanueva J, Santamaria R, Perez P (1993) Purification and characterization of a phenoloxidase (laccase) from the lignindegrading basidiomycete PM1 (CECT 2971). Appl Environ Microbiol 59(8):2607-2613

Daroch M, Houghton CA, Moore JK, Wilkinson MC, Carnell AJ, Bates AD, Iwanejko LA (2014) Glycosylated yellow laccase of the basidiomycete Stropharia aeruginosa. Enzyme Microb Technol 58:1-7

Decker H, Terwilliger N (2000) Cops and robbers: putative evolution of copper oxygen-binding proteins. J Exp Biol 203:1777-1782

Dong A, Yu Y, Yuan J, Wang Q, Fan X (2014) Hydrophobic modification of jute fiber used for composite reinforcement via laccase-mediated grafting. Appl Surf Sci 301:418-427 
Du X (2013) Deepening the insights of lignin structure: lignin-carbohydrate complex (LCC) fractionation and characterization and Kraft lignin amination. Dissertation, KTH Royal Institute of Technology

Elegir G, Kindl A, Sadocco P, Orlandi M (2008) Development of antimicrobial cellulose packaging through laccase-mediated grafting of phenolic compounds. Enzyme Microb Technol 43(2):84-92

Enguita FJ (2011) Structural biology of fungal multicopper oxidases. In: Leitao AL (ed) Mycofactories. Bentham Science Publishers, Emirate of Sharjah, United Arab Emirates, pp 57-72

Felby C, Thygesen LG, Sanadi A, Barsberg S (2004) Native lignin for bonding of fiber boards evaluation of bonding mechanisms in boards made from laccase-treated fibers of beech (Fagus sylvatica). Ind Crops Prod 20(2):181-189

Ferraroni M, Myasoedova N, Schmatchenko V, Leontievsky A, Golovleva L, Scozzafava A, Briganti F (2007) Crystal structure of a blue laccase from Lentinus tigrinus: evidences for intermediates in the molecular oxygen reductive splitting by multicopper oxidases. BMC Struct Biol 7(1):60

Gaitan IJ, Medina SC, González JC, Rodríguez A, Espejo Á, Osma JF, Sarria V, Alméciga-Díaz CJ, Sánchez OF (2011) Evaluation of toxicity and degradation of a chlorophenol mixture by the laccase produced by Trametes pubescens. Bioresour Technol 102(3):3632-3635

Garavaglia S, Cambria MT, Miglio M, Ragusa S, lacobazzi V, Palmieri F, D'Ambrosio C, Scaloni A, Rizzi M (2004) The structure of Rigidoporus lignosus laccase containing a full complement of copper ions, reveals an asymmetrical arrangement for the T3 copper pair. J Mol Biol 342(5):1519-1531

Givaudan A, Effosse A, Faure D, Potier P, Bouillant ML, Bally R (1993) Polyphenol oxidase in Azospirillum lipoferum isolated from rice rhizosphere: evidence for laccase activity in non-motile strains of Azospirillum lipoferum. FEMS Microbiol Lett 108(2):205-210

Hakulinen N, Kiiskinen L, Kruus K, Saloheimo M, Paananen A, Koivula A, Rouvinen I (2002) Crystal structure of a laccase from Melanocarpus albomyces with an intact trinuclear copper site. Nat Struct Mol Biol 9:601-605

Hattori M, Konishi H, Tamura Y, Konno K, Sogawa K (2005) Laccase-type phenoloxidase in salivary glands and watery saliva of the green rice leafhopper, Nephotettix cincticeps. J Insect Physiol 51(12):1359-1365

Hu D, Zhang R, Zhang G, Wang H, Ng TB (2011) A laccase with antiproliferative activity against tumor cells from an edible mushroom, white common Agrocybe cylindracea. Phytomedicine 18(5):374-379

Jaiswal N, Pandey VP, Dwivedi UN (2015) Purification of a thermostable alkaline laccase from papaya (Carica papaya) using affinity chromatography. Int J Biol Macromol 72:326-332

Johannes C, Majcherczyk A (2000) Natural mediators in the oxidation of polycyclic aromatic hydrocarbons by laccase mediator systems. Appl Environ Microbiol 66(2):524-528

Khan R, Bhawana P, Fulekar MH (2013) Microbial decolorization and degradation of synthetic dyes: a review. Rev Environ Sci BioTechnol 12:75-97

Kudanga T, Le Roes-Hill M (2014) Laccase applications in biofuels production: current status and future prospects. Applied Microbiol Biotechnol 98(15):6525-6542

Kulys J, Vidziunaite R (2003) Amperometric biosensors based on recombinant laccase for phenols determination. Biosens Bioelectron 18(2):319-325

Kumar S, Nussinov R (2001) How do thermophilic proteins deal with heat? Cell Mol Life Sci CMLS 58(9):1216-1233

Kumar SV, Phale PS, Durani S, Wangikar PP (2003) Combined sequence and structure analysis of the fungal laccase family. Biotechnol Bioeng 83(4):386-394

Leite O, Lupetti K, Fatibellofilho O, Vieira I, Barbosa A (2003) Synergic effect studies of the bi-enzymatic system laccase-peroxidase in a voltammetric biosensor for catecholamines. Talanta 59(5):889-896

Leontievsky A, Myasoedova N, Pozdnyakova N, Golovleva L (1997) Yellow'laccase of Panus tigrinusoxidizes non-phenolic substrates without electrontransfer mediators. FEBS Lett 413(3):446-448

Lin J, Zhang X, Li Z, Lei L (2010) Biodegradation of reactive blue 13 in a twostage anaerobic/aerobic fluidized beds system with a Pseudomonas sp. isolate. Bioresour Technol 101:34-40

Lloret L, Eibes G, Moreira M, Feijoo G, Lema J (2013) On the use of a high-redox potential laccase as an alternative for the transformation of non-steroidal anti-inflammatory drugs (NSAIDs). J Mol Catal B Enzym 97:233-242

Ludwig D, AmannM Hirth T, Rupp S, Zibek S (2013) Development and optimization of single and combined detoxification processes to improve the fermentability of lignocellulose hydrolysates. Bioresour Technol 133:455-461

Mahmoodi NM, Arami M, Gharanjig K (2009) Laboratory studiesand CFD modeling of photocatalytic degradation of colored textile wastewater by titania nanoparticles. Desalin Water Treat 1(1-3):312-317

Matera I, Gullotto A, Tilli S, Ferraroni M, Scozzafava A, Briganti F (2008) Crystal structure of the blue multicopper oxidase from the white-rot fungus Trametes trogii complexed with $p$-toluate. Inorg Chim Acta 361(14-15):4129-4137

Medina-Plaza C, de Saja JA, Rodriguez-Mendez ML (2014) Bioelectronic tongue based on lipidic nanostructured layers containing phenol oxidases and lutetium bisphthalocyanine for the analysis of grapes. Biosens Bioelectron 57:276-283

Mei LP, Feng JJ, Wu L, Zhou JY, Chen JR, Wang AJ (2015) Novel phenol biosensor based on laccase immobilized on reduced graphene oxide supported palladium-copper alloyed nanocages. Biosens Bioelectron 74:347-352

Morozova O, Shumakovich G, Shleev S, Yaropolov YI (2007) Laccase-mediator systems and their applications: a review. Appl Biochem Micro 43(5):523-535

Moț AC, Pârvu M, Damian G, Irimie FD, Darula Z, Medzihradszky KF, Brem B, Silaghi-Dumitrescu R (2012) A "yellow" laccase with "blue" spectroscopic features, from Sclerotinia sclerotiorum. Process Biochem 47(6):968-975

Mousty C, Vieille L, Cosnier S (2007) Laccase immobilization in redox active layered double hydroxides: a reagentless amperometric biosensor. Biosens Bioelectron 22(8):1733-1738

Nazari M, Kashanian S, Rafipour R (2015) Laccase immobilization on the electrode surface to design a biosensor for the detection of phenolic compound such as catechol. Spectrochim Acta Mol Biomol Spectrosc 145:130-138

Nazaruk E, Smoliński S, Swatko-Ossor M, Ginalska G, Fiedurek J, Rogalski J, Bilewicz R (2008) Enzymatic biofuel cell based on electrodes modified with lipid liquid-crystalline cubic phases. J Power Sources 183(2):533-538

Nguyen LN, van de Merwe JP, Hai FI, Leusch FD, Kang J, Price WE, Roddick F, Magram Nghiem LD (2016) Laccase-syringaldehyde-mediated degradation of trace organic contaminants in an enzymatic membrane reactor: removal efficiency and effluent toxicity. Bioresour Technol 200:477-484

Nicotra S, Cramarossa MR, Mucci A, Pagnoni UM, Riva S, Forti L (2004) Biotransformation of resveratrol: synthesis of trans-dehydrodimers catalyzed by laccase from Myceliophtora thermophyla and from Trametes pubescens. Tetrahedron 60(3):595-600

Niku-Paavola ML, Fagerström R, Kruus K, Viikari L (2004) Thermostable laccase produced by a white-rot fungus from Peniophora species. Enzyme Microb Technol 35(1):100-102

Osma JF, Toca-Herrera JL, Rodríguez-Couto S (2011) Cost analysis in laccase production. J Environ Manag 92(11):2907-2912

Palmieri G, Giardina P, Bianco C, Scaloni A, Capasso A, Sannia G (1997) A novel white laccase from Pleurotus ostreatus. J Biol Chem 272(50):31301-31307

Pang S, Wu Y, Zhang X, Li B, Ouyang J, Ding M (2016) Immobilization of laccase via adsorption onto bimodal mesoporous Zr-MOF. Process Biochem 51(2):229-239

Piacquadio P, De Stefano G, Sammartino M, Sciancalepore V (1998) Apple juice stabilization by laccase immobilized on metal chelate regenerable carriers. Industrie delle Bevande 27:378-83

Plácido J, Capareda S (2015) Ligninolytic enzymes: a biotechnological alternative for bioethanol production. Bioresour Bioprocess 2(1):23

Pozdnyakova NN, Rodakiewicz-Nowak J, Turkovskaya OV (2004) Catalytic properties of yellow laccase from Pleurotus ostreatus D1. J Mol Catal B Enzym 30(1):19-24

Pozdnyakova NN, Rodakiewicz-Nowak J, Turkovskaya OV, Haber J (2006) Oxidative degradation of polyaromatic hydrocarbons and their derivatives catalyzed directly by the yellow laccase from Pleurotus ostreatus D1. J Mol Catal B Enzym 41(1-2):8-15

Quan D, Kim Y, Shin W (2004) Characterization of an amperometric laccase electrode covalently immobilized on platinum surface. J Electroanal Chem 561:181-189

Ribeiro DS, Henrique SMB, Oliveira LS, Macedo GA, Fleuri LF (2010) Enzymes in juice processing: a review. Int J Food Sci Technol 45:635-641

Saastamoinen P, Mattinen ML, Hippi U, Nousiainen P, Sipilä J, Lille M, Suurnäkki A, Pere J (2012) Laccase aided modification of nanofibrillated cellulose with dodecyl gallate. BioResources 7(4):5749-5770 
Saito KO, Ikeda R, Endo K, Tsujino Y, Takagi M, Tamiya E (2012) Isolation of a novel alkaline-induced laccase from Flammulina velutipes and its application for hair coloring. J Biosci Bioeng 113(5):575-579

Salvachúa D, Prieto A, López-Abelairas M, Lu-Chau T, Martínez ÁT, Martínez MJ (2011) Fungal pretreatment: an alternative in second generation ethanol from wheat straw. Bioresour Technol 102:7500-7506

Saratale RG, Saratale GD, Chang JS, Govindwar SP (2011) Bacterial decolorization and degradation of azo dyes: a review. J Taiwan Inst Chem Eng 42:138-157

Selinheimo E, Kruus K, Buchert J, Hopia A, Autio K (2006) Effects of laccase, xylanase and their combination on the rheological properties of wheat doughs. J Cereal Sci 43(2):152-159

Singh G, Capalash N, Goel R, Sharma P (2007) A pH-stable laccase from alkalitolerant $\gamma$-proteobacterium JB: purification, characterization and indigo carmine degradation. Enzyme Microb Technol 41(6-7):794-799

Songulashvili G, Flahaut S, Demarez M, Tricot C, Bauvois C, Debaste F, Penninckx MJ (2016) High yield production in seven days of Coriolopsis gallica 1184 laccase at $50 \mathrm{~L}$ scale; enzyme purification and molecular characterization. Fungal Biol 120(4):481-488

Sun J, Chen QJ, Zhu MJ, Wang HX, Zhang GQ (2014) An extracellular laccase with antiproliferative activity from the sanghuang mushroom Inonotus baumii. J Mol Catal B Enzym 99:20-25

Surwase SV, Patil SA, Srinivas S, Jadhav JP (2016) Interaction of small molecules with fungal laccase: a surface plasmon resonance based study. Enzyme Microb Technol 82:110-114

Tabka MG, Herpoël-Gimbert I, Monod F, Asther M, Sigoillot JC (2006) Enzymatic saccharification of wheat straw for bioethanol production by a combined cellulase xylanase and feruloyl esterase treatment. Enzyme Microb Technol 39:897-902

Terrón MC, González T, Carbajo JM, Yagüe S, Arana-Cuenca A, Téllez A, Dobson AD, González AE (2004) Structural close-related aromatic compounds have different effects on laccase activity and on Icc gene expression in the ligninolytic fungus Trametes sp. I-62. Fungal Genet Biol 41(10):954-962

Ueda M, Shintani K, Nakanishi-Anjyuin A, Nakazawa M, Kusuda M, Nakatani F, Kawaguchi T, Tsujiyama SI, Kawanishi M, Yagi T, Miyatake K (2012) A protein from Pleurotus eryngii var. tuoliensis CJ Mou with strong removal activity against the natural steroid hormone, estriol: purification, characterization, and identification as a laccase. Enzyme Microb Technol 51(6):402-407
Viswanath B, Rajesh B, Janardhan A, Kumar AP, Narasimha G (2014) Fungal laccase and their applications in bioremediation. Enzyme Res. Article ID 163242

Xenakis A, Zoumpanioti M, Stamatis H (2016) Enzymatic reactions in structured surfactant-free microemulsions. Curr Opin Colloid Interface Sci 22:41-45

Xiang L, Lin Y, Yu P, Su L, Mao L (2007) Laccase-catalyzed oxidation and intramolecular cyclization of dopamine: a new method for selective determination of dopamine with laccase/carbon nanotube-based electrochemical biosensors. Electrochim Acta 52(12):4144-4152

Yamagishi K, Kimura T, Watanabe T (2011) Treatment of rice straw with selected Cyathus stercoreus strains to improve enzymatic saccharification. Bioresour Technol 102:6937-6943

Yoshida H (1883) Chemistry of lacquer (Urishi) part 1. J Chem Soc (Tokyo) 43:472-486

Yu Y, Wang Q, Yuan J, Fan X, Wang P, Cui L (2016) Hydrophobic modification of cotton fabric with octadecylamine via laccase/TEMPO mediated grafting Carbohydr Polym 137:549-555

Zebda A, Gondran C, Cinquin P, Cosnier S (2012) Glucose biofuel cell construction based on enzyme, graphite particle and redox mediator compression. Sens Actuators B Chem 173:760-764

Zhao J, Mou Y, Shan T, Li Y, Zhou L, Wang M, Wang J (2010) Antimicrobial metabolites from the endophytic fungus Pichiaguillier mondii isolated from Paris polyphylla var. yunnanensis. Molecules 15:7961-7970

Zhao D, Zhang X, Cui D, Zhao M (2012) Characterisation of a novel white laccase from the deuteromycete fungus Myrothecium verrucaria NF-05 and its decolourisation of dyes. PLOS ONE 7(6):e38817

Zheng W, Zhou HM, Zheng YF, Wang N (2008) A comparative study on electrochemistry of laccase at two kinds of carbon nanotubes and its application for biofuel cell. Chem Phys Lett 457(4-6):381-385

Zheng F, Cui BK, Wu XJ, Meng G, Liu HX, Si J (2016) Immobilization of laccase onto chitosan beads to enhance its capability to degrade synthetic dyes. Int Biodeterior Biodegrad 110:69-78

Zhu M, Zhang G, Meng L, Wang H, Gao K, Ng T (2016) Purification and characterization of a white laccase with pronounced dye decolorizing ability and HIV-1 reverse transcriptase inhibitory activity from Lepista nuda. Molecules 21(4):415

\section{Submit your manuscript to a SpringerOpen ${ }^{\circ}$ journal and benefit from:}

- Convenient online submission

- Rigorous peer review

- Open access: articles freely available online

- High visibility within the field

Retaining the copyright to your article

Submit your next manuscript at $\boldsymbol{~ s p r i n g e r o p e n . c o m ~}$ 